\title{
Factors Affecting Financial Performance of Insurance Industry in Pakistan
}

\author{
Kokab Shawar* \\ Research Scholar \\ Karachi University Business School, University of Karachi, Pakistan \\ Dr. Danish Ahmed Siddiqui \\ Associate Professor \\ Karachi University Business School, University of Karachi, Pakistan
}

\begin{abstract}
This study investigated the indicators of financial performance of insurance companies of Pakistan. Gross written premium (GWP), Claim (CLM), Reinsurance (Rei), Management expenditure (MGE), Interest rate (IR), Size (SIZ), Leverage (LEV), Real GDP (RGDP) were taken as factors (independent variables), whereas Sales Profitability (SAP), Investment Income (INP), and Underwriting profit (UWP) were taken as proxy of financial performance. Data of five 5 insurance companies are chosen covering the period of 2013-2017. Data was analyzed using panel regression. Findings showed that the gross written premium has the significant impact on all three measure of profitability. The further size of the company has a negative impact on sales and investment profit. In addition, the claims, reinsurance, GDP, interest rate and management expenses have an insignificant relationship with all three profitability measures. Hence, in order to improve operational and financial performance of the insurance industry in Pakistan, more focus should be given to factors that could increase premium.
\end{abstract}

Keywords: Growth, Financial Performance, Assessment, Financial stability, financial services, Insurance, Pakistan

DOI: $10.7176 / \mathrm{RJFA} / 10-5-03$

Publication date:March $31^{\text {st }} 2019$

\section{INTRODUCION}

\subsection{Background of the Research}

In any country financial performanceof any sector serves as a backbone of economic growth and industrialization of the country. Insurance sector has its own importance because it is responsible to provide proficient financial aid, channel funds, utilization of resources in optimal manner and investor's treatment. Under the umbrella of financial sector, Insurance sector plays a pivotal role of regulating funds to different industries thereby contributing major inflows towards economic and financial growth (Andrieş \& Căpraru, 2014). Insurance sector is considered to be well-established if it has the ability of pacifying any sort of financial crisis in the economy hence, strengthening the economic system of the country.

Insurance is a process of risk transfer which shields the enthusiasm of average folks from future dubious misfortune Insurance likewise gives budgetary help to decrease the danger of human life and their properties (Ari f\& Showket 2013). An Insurance approach is an assertion between insurance agencies and policyholder which cover a few dangers according to request and need of guaranteed. The idea of Insurance isn't new it is really embraced from the most punctual period of human advancement, sharing of hazard to help each other at the season of misfortune or hardship were so normal. For the most part, brokers and vendors had utilized that idea to dodge vulnerability. In this time Insurance is so normal and accessible practically entire over the world and as indicated by Federal Insurance ombudsman Pakistan (FIOP) that exchange is ending up increasingly worldwide. The innovation is changing and is being supplanted at a quicker rate. In this substantially more unsure world Insurance is necessary and it is likewise assuming an imperative job in lessening the hazard load on people and organizations. The Insurance business of Pakistan isn't as bigger than other creating nations yet can possibly influence the GDP (SECP, July 2016). The Insurance division of Pakistan is isolated into real two classes, Takaful, and traditional Insurance. Further the two classes likewise partitioned into two subclassifications, Life Insurance, and non-disaster Insurance. To spread the hazard reinsurance exercises are likewise completed in Pakistan. Insurance part giving a few coverages' which are Fire, engine, marine, flying, travel, wellbeing, money in Transit, Cash in Safe, life, individual mishap and misc. it is seen that the necessity of Insurance is exceptionally relative in an urban zone as opposed to country zones. As of now, 47 insurance agencies are giving insurance provider administrations. In which 37 organizations are non-life, 1 organization does reinsurance and 9 are life coverage organizations including family Takaful which is as of late presented in Pakistan (SECP July 2016). As figure 1 obviously appearing and solid development of extra security part of Pakistan in term of gross composed premium. In most recent seven-year, it is seen that the development rate of 
an industry is very nearly 20 to $30 \%$ yearly.

It is seen that amid 2014, complete premium composed by 51 regular and Takaful Insurance firms are around 184 billion. In which only 7 extra security organizations contribute 122 billion out of 48 Insurance organizations (Insurance yearbook 2014-15). This is appearing enormous contrast between non-life and disaster Insurance organizations. And furthermore show the high commitment of extra security area. There are a few sorts of research have been directed entire over the world. However sadly, in Pakistan, only a couple of scientists have been made them

Endeavors on the Insurance area. Thusly, it is essential to discover those inward factors which have the effect between non-life and extra security organizations and elements which are vital for the execution of an insurance agency.

\subsection{Problem Statement}

Insurance Sector in Pakistan has evolved over the last few decades and has expanded the horizon of services. In the last two decades, number of Insurance Company has almost doubled. The competition among them has gained height as the services and the products offered to its consumers have expanded. To help up and expand the proprietor's capital and win more benefit is the center reason and reason perpetually presence of any organization or industry. That is the reason benefit is one of the principal and vital variables of monetary administration to quantify and make future arranging and techniques of handling the basic circumstances. Hifza (2011) found a vacillation amid the period from 2005 to 2009 of the money related yearly reports of back up plans of Pakistan and base on that the investigation was directed and further proposed that it is essential to discover the variety among Insurance company's benefit. To decide the execution of insurer is a critical talk for the strategy creators and controllers to help the Insurance area in achieving the achievement and flawlessness. The pattern of Insurance segment is expanding step by step because of the basic circumstance of nation, increment in risk and vulnerability.

The Insurance part of Pakistan isn't as much enormous contrasted with other creating nations yet because of the basic circumstance of nation everybody needs to anchor his/her property and their lives. As plainly previous performance demonstrating that Government possessed organization SLIC is slowly losing its piece of the overall industry. What's more, privately owned businesses developing massively and appears to be extreme challenge between two prevailing organizations EFU and Jubilee life. As the general market drift demonstrating sound development which would effect on SCLI yet Surprisingly, SCLI is losing its piece of the pie. Also, as Takaful has as of late presented in Pakistan so the piece of the pie isn't sufficient then other traditional key players of life coverage. So it's a decent time to comprehend the key factor of productivity to catch more pieces of the overall industry. The life coverage industry inside the nation has encountered solid development, regarding gross premiums. So it is vital to discover key factor of Insurance benefit for controllers, strategy creators, safety net providers and experts to help the disaster Insurance industry in accomplishing the development and solidness which eventually prompts the general achievement of the economy

Sadly, in Pakistan, there are not as much research led on Insurance area thusly other created and creating nations. To satisfy the hole, it is basic to discover those autonomous factors or vital components which are assuming an essential job in the gainfulness of Insurance area or an individual organization. What's more, this examination will assist the policymakers and investors to evaluate the gainfulness of Insurance industry in Pakistan. (Căpraru \& Ihnatov, 2014). Therefore, it is essential to evaluate the performance of insurance companies in terms of their financial standings in regards with the perception through regulators, managers, potential investors, owners and depositors (Agapova, \& McNulty, 2016).

The study at hand is conducted to evaluate the performance of entire insurance industry by employing the financial ratio by using the data from 2008 to 2017 a period of ten years. The research can be deemed as most significant for the students who aim to contribute as devoted employees in the insurance industry. It would provide them with the insights of the financial performance of Pakistani insurance companies, which would further help them to understand the changing trends and mobilization in the industry. In addition to this, the research is significant for the higher management of insurance as it reflects on their practices and financial standings along with the identification of its segmentation. Lastly, the research is significant for futureresearchers, who can extract the findings of this research to base their papers on and explore different dimensions of insurance sector in Pakistan.

\subsection{Gap Analysis}

The literature on this topic is scarce, Salim (2018) conducted a study to examine the financial performance of the insurance companies in Bangladesh during the period of 1983-2012. The study was conducted on the data gathered for profitability measures before, during and after a period of financial liberalization. However, the focus of this study was limited to analyses of the effect of financial liberalization. Antoun et al., (2018) conducted a study with the aim of investigating the financial performance of the Central and Eastern European 
insurance companies. Their research covered the period 2009-2014. Selvam and Miencha (2013) conducted a study to analyze the financial performance of Kenyan Insurance companies. The data was collected from January 2007 to December 2011 ussingData Envelopment Analysis (DEA). However, since DEA is non-parametric estimations, one cannot test for the significance. The research of Abdel (2014) analyzed the financial performance of Insurance companies in Pakistan, with their sole focus on the private sector of the industry. He evaluated 10 private Insurance of Pakistan as its sample size. The research of Ahmed, N., Ahmed, Z. \& Usman, A. (2015) discusses the profitability and its determinants within the Insurance industry of Pakistan. The objective of this research was to compare profitability of the Insurance and the industry during the period of 2006 to 2010 . The research of Anila (2015) has discussed the importance of investment Insurance in the development of the country's economy because of its influence in the money and capital market. The research of Naseem (2012) investigated the financial performance of Pakistani Insurance companies by using the data for these Insurance from the year 2007 to 2011 . The study highlighted the specified period as most significantly prospering one for the Pakistani Insurance in terms of their performance financially. Anila (2017) evaluated the financial performance of Insurance industries in regards with the impact experienced by intellectual capital. The research is based on the data and information extracted from the reports of various Insurance. The approach taken for this study is VAIC (Value Added Intellectual Coefficient) in order to analyze the performance of on the basis of Insurance' efficiencies.

The research gap related to the study carried out by Abdel (2014) was that it was only focused on the private sector of the insurance industry and the study has not provided in-depth determination of all factors. Anila (2015) have also focused just on the investment Insurance and there is need of further research on the other factors affecting the financial activities and performance of different insurance companies. Furthermore, Naseem (2011) has described the topic in detail, yet the data used for this research was old ranging from 2007 2011 and to understand current trends, the research studies integrating old as well as new data are required. Further, another research gap is that the gross written profit, claim, reinsurance, management expenditure, interest rate, RGDP, size \& leverage are not considered for determination of financial performance of insurance companies.

While above studies provided sufficient correlation between various variables to assess the insurance company's financial strength, however, there have no study conducted in Pakistan that assess the financial performance ofinsurance companies in terms of gross written profit, claim, reinsurance, management expenditure, interest rate, RGDP, size \& leverage. Pakistan being developing country with long history of insurance, Therefore, the current study at hand is the contribution to the existing literature of insurance industry of Pakistan.

\subsection{Research Question}

The research questions to indicate the financial performance of Insurance industry of Pakistan are as follows:

1. Does Gross written profit (GWP) have significant impact on SAP, INP \& UWP?

2. Does Claim (CLM) have significant impact on SAP, INP \& UWP?

3. Does Reinsurance (Rei) have significant impact on SAP, INP \& UWP?

4. Does Management expenditure (MGE) have significant impact on SAP, INP \& UWP?

5. Does interest rate (IR) have significant impact on SAP, INP \& UWP?

6. Does size (SIZ) has significant impact on SAP, INP \& UWP?

7. Does Leverage (LEV) has significant impact on SAP, INP \& UWP?

8. Does Real Gross domestic product (RGDP) have significant impact on SAP, INP \& UWP?

\subsection{Outline of the Study}

This research consists of five chapters. Second sectioncovered literature review discussing previous studies. The third sectionexplained theoretical framework. Section four covered research methodology that describes data collection method, sample size and statistical techniques that are being used. Sectionfive analyzed the Insurance industry of Pakistan. Section 6 explained results that discuss the findings and their interpretation as well as hypothesis summary. Last sectionconcluded the research and also illustrates practical implications along with recommendations for future research work.

\subsection{Operational Definition}

Financial Performance: Financial performance is the ability of the firm of using its primary assets and convert it into revenue or profit

Interest rate: Interest rate is the percentage of the amount that is charged by the lender to the borrower for the usage of assets.

Economic growth: Economic growth can be defined as the increase in the value of goods or services generated by the economy over the period of time in an inflation-controlled market. 
Asset: An asset can be defined as any resource that is owned by a business. It could be any tangible or an intangible that is owned by the company to generate positive outcome.

\section{Literature Review}

The literature on this topic is scarce, Salim (2018) conducted a study to examine the financial performance of the insurance companies in Bangladesh during the period of 1983-2012. The study was conducted on the data gathered for profitability measures before, during and after a period of financial liberalization. According to his results financial reform did not have significant effect on the return on asset (ROA) or return on equity (ROE) however, net interest margin (NIM) has increased. Further, it was stated that capital and asset should be maintained through reliable policies as they are the important drivers of profitability. However, the focus of this study was limited to analyses of the effect of financial liberalization. Antoun et al., (2018) conducted a study with the aim of investigating the financial performance of the Central and Eastern European insurance companies. Their research covered the period 2009-2014. The FPI was constructed based on CAMEL ratios and then rendered on computed index. They also used fixed-effect panel regression and found that the size has negative effect on asset quality, earnings of insurance companies, Capital adequacy and liquidity whereas, insurance concentration and economic growth have positive effect.

Selvam and Miencha (2013) conducted a study to analyze the financial performance of Kenyan Insurance companies. The data was collected from January 2007 to December 2011. Using Data Envelopment Analysis (DEA) it was found that private insurance companies are performing better than public insurance companies and foreign insurance companies. However, since DEA is non-parametric estimations, one cannot test for the significance.

The research of Abdel k., (2014) analyzed the financial performance of Insurance companies in Pakistan, with their sole focus on the private sector of the industry. He evaluated 10 private Insurance of Pakistan as its sample size. The findings of this research indicated that the operational efficiency and size of the company are adversely associated with the Return on Assets; while on the other hand, a positive relation was found between size of company with operational efficiency and Asset Management Ratio. In addition to this, the research summarizes Asset Management and Interest Income to be positively related with the size of the company, while Interest Income is found to have a negative relation with operational efficiency.

The research of Ahmed, N., Ahmed, Z. \& Usman, A. (2015) discusses the profitability and its determinants within the Insurance industry of Pakistan. The objective of this research was to compare profitability of the Insurance and the industry during the period of 2006 to 2010. The study further evaluated the correlation between macroeconomics and Insurance company features through investigating the impact of different factors, such as market capitalization, inflation, economic growth, equity, deposits, assets and loans on the measures of profitability; net interest margin, return on capital employed, return on assets, return on equity. The impact was evaluated through the usage of Pooled Ordinary Least Square or POLS, which resulted in the strong impact of external and internal factors on the Insurance' profitability.

The research of Anila (2015) has discussed the importance of investment Insurance in the development of the country's economy because of its influence in the money and capital market. It was highlighted that these Insurance tend to support different businesses to grow, thus contributing in stabilizing the economic conditions. The research performed a financial analysis through implementing financial rations of Insurance sector, with the focus on investment Insurance in Pakistan, covering the period from year 2007 to 2011. The research was based on the contribution of the Insurance and the impact of several factors, such as financial measures, leverage, liquidity, efficiency and profitability along with the size of the company amongst many financial measures. Findings of the research indicated that the profitability of the Insurance lowered because of the great economic recession, however, the performance was found to be adequate. It concluded that the success of Insurance sector is not dependent on the economic conditions or scale of the country. However, the research lacks in performing analysis of the consumer behavior and the impact of economic conditions on the consumer Insurance and public sector.

The research of Naseem (2012) investigated the financial performance of Pakistani Insurance companies by using the data for these Insurance from the year 2007 to 2011. The study highlighted the specified period as most significantly prospering one for the Pakistani Insurance in terms of their performance financially. Findings of this research include the analysis of five top scheduled Insurance. The research was carried out to investigate the financial performance through using financial ratios such as Return on Capital, Return on Assets, and Return on Equity in contrast with variables such as operational efficiency and its ratios. The strength of this research is that it has also discussed the financial performance of Insurance in regards with the ROFA (Return on Operating Fixed Assets), which refers to the way operating fixed assets are being used by the Insurance and the way it contributes in its financial performance. In addition to this, the research investigated an impact of higher amount of total operating fixed assets, total equity and total assets, suggesting that these elements have no impact the improved performance of the Insurance Company. 
Anila (2017) evaluated the financial performance of Insurance industries in regards with the impact experienced by intellectual capital. The research is based on the data and information extracted from the reports of various Insurance. The approach taken for this study is VAIC (Value Added Intellectual Coefficient) in order to analyze the performance of on the basis of Insurance' efficiencies. Structural capital, human capital, return on assets and other financial instruments are used to measure the financial performance of Pakistani Insurance through applying the technique of multiple regressions. The findings of the research indicate that the VAIC value is higher in the case of conventional Insurance when they were contrasted with the Islamic Insurance. Moreover, the most significant driver in the Insurance industry of Pakistan in regards with the intellectual capital performance is the Human Capital efficiency. Hence, the study results in a positive association between VAIC and ROA, while the performance of Insurance reflected mixed outcomes. The weakness of this research reflects on its lack of including variety of Insurance in the notion, specifically leaving behind microfinance Insurance, specialized Insurance and foreign Insurance. However, the biggest strength of the research can be said that it provides a useful foundation of VAIC approach for the conventional Insurance for those who are positioned as policy makers. Moreover, it is considered as one of the most exclusive researches that focused on the financial performance of Insurance through evaluating the intellectual capital in Pakistan.

Dr. Amal (2012) consider the determinant of execution of money related exercises of Jordanian Insurance industry. The target of this examination is to research the best factors of the money related execution of Insurance area. Use, Age of the organization, Size of back up plans, liquidity, the ability of the board are considered as autonomous variable and 25 organizations information of the time of 2002 to 2007 assesses by utilizing relapse display. At long last, the outcome demonstrates that Leverage, proportion of liquidity, Size of guarantors, the ability of the executives list positively affects the execution of budgetary exercises. Before long YauandRazak. (2012) ponder on the item decent variety, use and the execution of general protection part of Malaysia by utilizing information from 2006 to 2009 of non-life coverage organizations in Malaysia. Backup plan execution, use, item decent variety, insurance company size, period and piece of the overall industry has been utilized as factors. At long last, the consequence of this investigation demonstrates that the use is adversely connected with back up plan's execution. The examination likewise shows that use could be gainful or negative to the budgetary execution of non-extra security firms.

Ashfaq and Saeed (2017) evaluated the impact of Corporate Governance Index on the performance of firm's earning management, which falls under the consideration of financial and insurance industry of Pakistan. The research was conducted under generalized method of movement for analysis, while different elements were evaluated such as Return on Assets, Book Value of Equity, Financial Institutions borrowings, non-performing loans, loan loss provision and corporate governance index. The Insurance were evaluated on the basis of their performance in between the years 2005 and 2015. The findings of this research discussed all variables and identified a negative coefficient for loan loss, indicating that it has adverse impact on the profitability of the Insurance companies. The research concludes that each variable has a significant impact on the Pakistani Insurance financial performance. On the other hand, the non-performing loans projected no impact on the performance of Insurance financially.

Juliana et al. (2012), research the determinants of Family Demand of Malaysian protection industry. The center reason for this investigation is to discover the determinants of family Islamic insurance necessity and require and to make of investigating an alternate model for determinants of family Islamic protection prerequisite. The investigation finishes up period from 2005 to 2009 of Malaysian insurance agencies. In last the outcome demonstrates that as pay, the cost of Takaful, future, loan cost, stocks, instruction, age, budgetary improvement, annuities, reliance proportion, urbanization, size and business status regarding their families' Islamic protection prerequisites has the positive relationship. In any case, on the opposite end swelling of a nation, funds of every family and joblessness rate with family Islamic protection necessities has the negative relationship

Hsu-Hua et al. (2012) direct an examination on protection company's execution and concentrate the investigation of reinsurance of property obligation of Taiwan and the investigation additionally consider the connection among reinsurance and friend's execution, the exploration incorporated the firm size, Leverage, UR chance, Line of Business, Growth premium. Liquidity proportion, Reinsurance, ROI, and Holdings are as factors. The information of 15 property obligation insurance agencies is gathered and subsequent to covering the period from 1999 to 2009 to discover the outcomes. At last, the consequence of the examination demonstrates that protection endorsing, ROA, a line of business focus, ROI, liquidity proportion and sham budgetary holding have a positive huge relationship with the needy variable. Further, it is seen that the reinsurance, guaranteeing dangers, firm size, and money related influences, liquidity and degree of profitability emphatically and essentially impact on insurance company's execution.

\subsection{Conceptual Framework}

The conceptual framework of this research study has been designed by taking into consideration the theoretical concepts of agency theory, stakeholder theory, and theory of optimal structure. 


\subsubsection{Agency Theory}

According to agency theory, the analysis of the firm must be carried out separately in terms of control, ownership and motivation. As demonstrated by this theory, the mismatch of the interest of debt holders, shareholders and management can affect the net profit of the firms and thus demonstrates the financial performance of the firms. The agency theory is considered as a significant framework for the purpose of designing the governance as well as controlling the organizations (Bosse \& Phillips, 2016).

2.1.2 Stakeholders Theory

The stakeholder theory is described as the theory of organizational management and this theory has been used by the organizations to manage the profitability of the firms. According to stakeholder theory, the management of the risks can increase the significance of financial distress cost and customer trust and taking into consideration the management of risks is effective to overcome the financial issues. It is used to determine the performance by the use of different variables (Ferretti, 2016).

2.1.3 Theory of Optimal Capital Structure

On the other hand, the theory of optimal capital structure explained that the external and internal cost of risk management must be balanced (Brusov, Filatova, Orekhova, \& Eskindarov, 2018). The conceptual framework for this research study is given below;

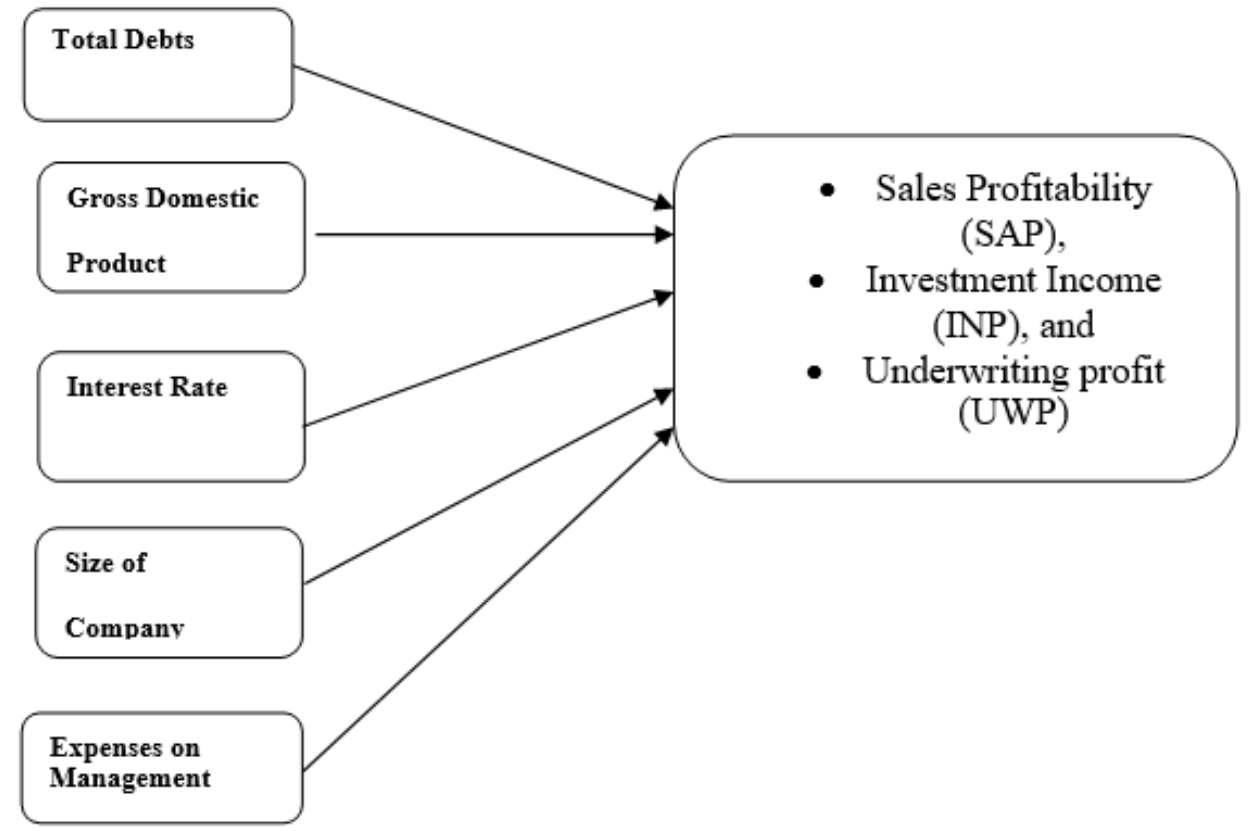

Sales Profitability: It is referred to as the ability of a business to generate revenue through sales and earn profit on it.

Investment Income: Investment income is defined as the money or revenue generated from the investment made.

Underwriting profit: The underwriting profit is most commonly used in the context of financial insurance industry and indicates the earned premium after enduring expenses related to administration and loss.

Gross Domestic Product: Gross Domestic Product or GDP is a measure of monetary value of any given services or goods for the specified duration. It is used to understand, evaluate and analyze the performance of economy of a country.

Interest Rate: Interest rate is defined as the amount charged over loan as the interest on the person who borrowed. In general, it is a percentage of the actual loan which is charged on the loan outstanding.

Size of Company: Size of the company is referred to the total assets of the company.

Total Debts: Total debt can be referred to as the combination of long term and short term debts.

Expenses on Management: It is defined as the cost incurred for the operational consistency of managing unit or mutual funds, which is often charged against the income it generates.

\section{Industry analysis}

The insurance company is the term, which is used to present the business, which can provide coverage as compensation generated from injury, hardship, treatment, damages and loss in exchange of the premium payments made by the customers. The company consider the risk of occurrence of any incident and then evaluate the cost, which is required for replacing the loss with respect to premium cost. The insurance industry in 
Pakistan provides the considerable and long-term potential for growth because of population of the country and decreased level of insurance coverage provided by the industry. The insurance companies have penetrated $0.6 \%$ in the life sectors and $0.3 \%$ in the non-life sectors and this coverage level is very low as compared to other markets. However, the increase in the income level as well as expansion of middle class will boost this industry in few years.

The strengths of this sector include the chances of business growth and emerging middle income group and rise in income per capita. However, different weakness of insurance sector includes low investment, limited facilities and old tariff structure. The opportunities for this sector include the development of strong demand, chances of future growth, and increase in the awareness of people about health insurance. The threats associated with insurance sector included no constructive change in the policy and worse legal and financial infrastructures. Currently, there are limited players in the insurance market and some companies are providing the major market share for the company. It is expected that the insurance sector will affect the economic and social structure of the country in the up-coming years as the percentage of growth during last few years is $30-35 \%$. Yet the economic and regulatory condition of the country are major challenges to this industry. EFU life insurance ltd., UBL Insurers Limited, Dawood Family Takaful Limited, Pak Qatar Family Takaful, and State Life are some examples.

\begin{tabular}{|c|c|c|c|c|c|}
\hline \multicolumn{6}{|c|}{ INSURANCEPENETRATION IN PAKISTAN } \\
\hline \multicolumn{6}{|l|}{$2.00 \%$} \\
\hline \multicolumn{6}{|l|}{$1.80 \%$} \\
\hline \multicolumn{6}{|l|}{$\begin{array}{l}1.60 \% \\
1.40 \%\end{array}$} \\
\hline $1.40 \%$ & $0.73 \%$ & & & & $0.71 \%$ \\
\hline $1.20 \%$ & & & & & \\
\hline $1.00 \%$ & & & & 0 & \\
\hline $0.80 \%$ & $0.26 \%$ & c & 0 & & $0.19 \%$ \\
\hline $0.60 \%$ & & & 0 & 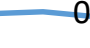 & $0.52 \%$ \\
\hline $0.40 \%$ & $0.41 \%$ & & & & \\
\hline $0.20 \%$ & & & & & \\
\hline $0.00 \%$ & 2013 & 2014 & 2015 & 2016 & 2017 \\
\hline
\end{tabular}

\section{Conventional Business}

Life Insurance Companies

No of Companies

Gross Premium Written

Premium to GDP Ratio
7

PKR 199.34 Billion $0.50 \%$

Takaful Business

Window Takaful Operators

No. of Companies

Gross Written Contribution

Contribution to GDP Ratio
PKR 11.71 Billion $0.02 \%$ 
Currently, there are 7 life insurance companies operate in the country. State Life Insurance Corporation Limited, a state owned player, leads in gross premiums as it generates almost three-fifth of the industry's premium. Furthermore, private sector's landscape is dominated by two players, namely Jubilee Life Insurance Limited (JLI) and EFU Life Assurance Limited (EFU). Contribution of takaful operators remains minimal on account of lack of general awareness about takaful products and services. Following table of market share is given below.

\begin{tabular}{|c|c|c|}
\hline Life Insurance Competitors & \multicolumn{2}{c|}{ Market Share } \\
\hline & $\mathbf{2 0 1 7}$ & $\mathbf{2 0 1 6}$ \\
\hline State Life Insurance Corporation of Pakistan & $50.69 \%$ & $52.44 \%$ \\
\hline Jubilee Life Insurance Corporation & $23.64 \%$ & $22.12 \%$ \\
\hline EFU Life Assurance & $15.80 \%$ & $14.37 \%$ \\
\hline IGI Life Insurance & $2.82 \%$ & $4.41 \%$ \\
\hline Adamjee Life Insurance & $6.91 \%$ & $6.58 \%$ \\
\hline East West Life Insurance & $0.01 \%$ & $0.01 \%$ \\
\hline TPL Life Insurance & $0.14 \%$ & $0.07 \%$ \\
\hline Total Market Share Percentage & $100.00 \%$ & $100.00 \%$ \\
\hline
\end{tabular}

General Insurance Companies in Pakistan are also competing with each other, there are more general insurance companies and few life insurance companies in Pakistan.

\begin{tabular}{|c|c|}
\hline \multicolumn{2}{|c|}{ General Insurance Competition } \\
\hline Adamjee Insurance & Habib Insurance \\
\hline Alfalah Ins. Co & IGI Insurance \\
\hline Allianz EFU Health & Jubilee General Ins. \\
\hline Alpha Insurance & New Hampshire Ins. \\
\hline Asia Insurance & Pakistan Gen. Ins. \\
\hline Askari Gen. Insc. & Premier Ins. \\
\hline Atlas Insurance & Reliance Insurance \\
\hline Century Insurance & SPI Insurance \\
\hline Cooperative Ins. & Security Gen. Insc. \\
\hline Crescent Star & Shaheen Ins. \\
\hline East West Insc. & Sindh Insurance \\
\hline EFU Gen. Ins. Ltd. & TPL Insurance Ltd. \\
\hline Excel Insurance & UBL Insurer \\
\hline
\end{tabular}

\section{Research Methodology}

\subsection{Research Design}

Research design refers to the strategy a researcher formulates to progress his research. It includes determining the nature of the research, along with selecting appropriate methods to approach and collect information. It also includes the specification of sample size and type while discussing the way in which that collected information is analyzed and presented in the form of results. Furthermore, it reflects on the methods and techniques used to draw a conclusion or to validate or reject the hypothesis of the research (Lewis, 2015). However, the research design is formulated after understanding the requirement of the research in order to produce results that are relevant and valid. In this research, dependent variables that are Sales Profitability, Investment Income and Underwriting profit are evaluated on the basis of the impact of GWP, CLM, Rei, GDP, INR, SIZ, LEV, and MGE that are independent variable.

\subsection{Sample Size}

Sample size is considered as a pool of entities that reflect an entire population. In the context of this research, the entities are insurance companies of Pakistan. Therefore, the sample size for this research includes 5insurance companies and the data is collected through their financial reports that were presented during last 5 years that was 2013-2017. The financial reports of these insurance companies are available on internet. All the relevant reports of 2013-2017 were accessed from the official websites of the companies.

\subsection{Model Equation}

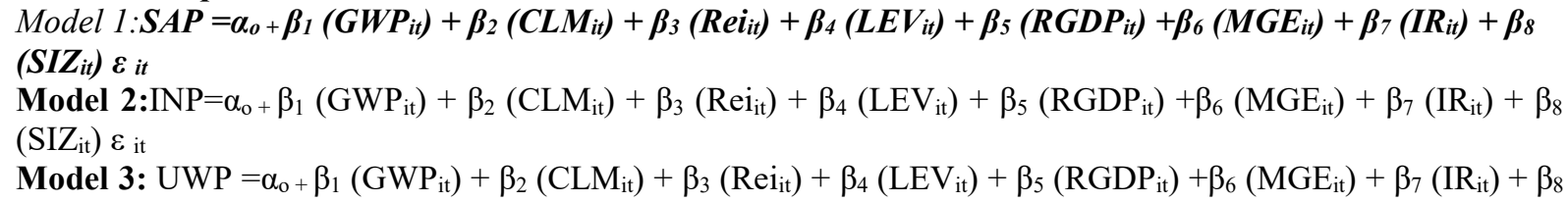


$\left(\mathrm{SIZ}_{\mathrm{it}}\right) \varepsilon_{\text {it }}$

\subsection{Statistical Technique}

Statistical techniques, methods and mathematical formulas are used to evaluate raw data through statistical analysis. It forms the equation and association between the variables discussed in the research through different approaches. In order to investigate the financial performance and impact of financial ratios on the profitability of Pakistani insurance companies, regression analysis has been used as a form of statistical technique along with the Hausman test. Regression analysis refers to the technique that identifies the association or relationship between independent and dependent variables (Bollen et al (2016). On the other hand, the purpose of Hausman test is to identify and differentiate between random effects model and fixed effects model to test the hypotheses (Lu and White, 2014)

\section{Results}

\subsection{Data Summary}

The research was purely secondary in nature. In this research the data was collected through the annual reports of Insurances companies that are listed at Karachi stock exchange. The variables that were chosen in this research were Gross written premium (GWP), Claim (CLM), Reinsurance (Rei), Management expenditure (MGE), Interest rate (IR), Size (SIZ), Leverage (LEV), Real GDP (RGDP) were independent variables and Sales Profitability (SAP), Investment Income (INP), and Underwriting profit (UWP) was dependent variables.

After the descriptive analysis the below table showed the value of mean, standard deviation, minimum and maximum, the mean value of Gross written premium (GWP) 6.954, Claim (CLM) 2.431, Reinsurance (Rei) 4.321, Management expenditure (MGE) 0.065, Interest rate (IR) 18.85, Size (SIZ) 0.431, Leverage (LEV) 4.312, Real GDP (RGDP) 0. 119.whereas dependent variable mean was Sales Profitability (SAP) 7.832, Investment Income (INP) 1.108, and Underwriting profit (UWP) 1.092.

When checking standard deviation Gross written premium (GWP), Claim (CLM), Reinsurance (Rei), Management expenditure (MGE), Interest rate (IR), Size (SIZ), Leverage (LEV), Real GDP (RGDP) and Sales Profitability (SAP), Investment Income (INP), and Underwriting profit (UWP) showed average standard deviation which indicate data has few variations and fluctuation.

Table 5.1

Descriptive Statistics

\begin{tabular}{cllcrcr}
\hline S. No. & Variables & Definition & Mean & Std. Dev. & \multicolumn{1}{c}{ Min. } & Max. \\
\hline 1 & MGE & Management Expenditure & 0.065 & 0.277 & 0.000 & 1.000 \\
2 & IR & Interest Rate & 18.85 & 1.456 & 8.110 & 14.89 \\
3 & SIZ & Size & 0.431 & 1.248 & 0.000 & 0.930 \\
4 & LEV & Leverage & 4.312 & 0.578 & 1.000 & 13.00 \\
5 & RGDP & Real GDP & 0.119 & 0.055 & 0.000 & 0.340 \\
6 & GWP & Gross written premium & 6.954 & 2.128 & 7.010 & 22.17 \\
7 & CLM & Claim & 2.431 & 0.248 & 0.000 & 3.930 \\
8 & Rei & Reinsurance & 4.312 & 1.578 & 1.000 & 16.00 \\
6 & SAP & Sales Profitability & 7.832 & 0.856 & 5.104 & 11.61 \\
7 & INP & Investment Income & 1.108 & 0.769 & 7.213 & 9.189 \\
8 & UWP & Underwriting Profit & 1.092 & 0.147 & 0.000 & 8.118
\end{tabular}

\subsection{Hausman Test}

Two techniques were used to analyze panel data: one is fixed and other one is random effect. In order to select between these two This Hausman test is used as cross sectional approach after the after the panel least in order to get more filtered and visible results The test is applied for the purpose for checking overall random or fixed effect at model. The given hausman test which showed correlated random effects with the probe value which was $(<0.05)$ showed significant impact of insurancecompany profitability. The following result further described that it will be sufficient to better generalize the overall model with the help of cross section fixed effect in order to support the research purpose.

Table 5.2

Correlated Random Effects - Hausman Test

\begin{tabular}{|l|l|l|l|l|}
\hline S.No & Variable & Chi.sq & df & Prob \\
\hline $\mathbf{1}$ & SAP & 109.59 & 4 & 0.000 \\
\hline $\mathbf{2}$ & INP & 20.480 & 4 & 0.004 \\
\hline $\mathbf{3}$ & UWP & 23.254 & 4 & 0.003 \\
\hline
\end{tabular}




\subsection{Cross-section Fixed Effect Regression}

The following cross section random effect model gives the complete analysis of each individual variable that defines profitability which is Sales profitability, Investment Income, Underwriting profit.

Table 5.3

Panel Analysis with Fixed Effects

\begin{tabular}{llll}
\hline & Model 1 & Model 2 & Model 3 \\
\hline Dependent variable & SAP & INP & UWP \\
\hline GWP & $\mathbf{0 . 4 5 2 1}$ & $\mathbf{0 . 1 1 3 5}$ & $\mathbf{0 . 9 9 9}$ \\
\hline CLM & $(0.001)$ & $(0.001)$ & $(0.001)$ \\
\hline & $\mathbf{0 . 0 2 8 7}$ & $\mathbf{0 . 3 1 1 7}$ & $\mathbf{- 8 . 6 8 E}$ \\
\hline Rei & $(0.675)$ & $(0.422)$ & $(0.614)$ \\
\hline & $\mathbf{- 0 . 0 7 2}$ & $\mathbf{- 1 . 7 0 1 3}$ & $\mathbf{- 3 . 5 2 5}$ \\
\hline MGE & $(0.823)$ & $(0.353)$ & $(0.312)$ \\
\hline & $\mathbf{0 . 0 5 5}$ & $\mathbf{- 0 . 0 8 6}$ & $\mathbf{0 . 0 9 1}$ \\
\hline IR & $(0.216)$ & $(0.000)$ & $(0.000)$ \\
\hline & $\mathbf{0 . 0 4 6}$ & $\mathbf{- 0 . 0 4 9}$ & $\mathbf{- 0 . 1 5}$ \\
\hline SIZ & $(0.25)$ & $(0.513)$ & $(0.005)$ \\
\hline & $\mathbf{- 0 . 0 6 6}$ & $\mathbf{- 0 . 1 1 2}$ & $(0.942$ \\
\hline LEV & $(-0.041)$ & $(0.000)$ & $\mathbf{0 . 3 3 3}$ \\
\hline & $\mathbf{- 0 . 0 3 9}$ & $\mathbf{0 . 2 1 5}$ & $(0.75)$ \\
\hline RGDP & $(0.000)$ & $(0.51)$ & $\mathbf{- 0 . 0 4 9}$ \\
\hline & $\mathbf{- 0 . 0 8 6}$ & $\mathbf{- 0 . 1 5}$ & $(0.513)$ \\
\hline R Square & $(0.000)$ & $(0.255)$ & $\mathbf{0 . 6 2 1 8}$ \\
\hline Prob F-Statistics & $\mathbf{0 . 5 4 1 8}$ & $\mathbf{0 . 6 9 1 8}$ & $(0.000)$ \\
\hline
\end{tabular}

The value of coefficient summarizes the regression equation's aftereffects. So from coefficient table the variables which sig value is $(>0.05)$ point towards the rejection of that hypothesis and shows insignificant impact between independent variable which were CLM, Rei, MGE, IR, SIZE and dependent variable SAP, whereas GWP, LEV and RGDP shows significant impact on SAP. The section B values examine the degree to which independent variable's estimation sum up to the dependent variable's estimation. Whereas "T value" which defines those variables that are independent contribute to the variable that was dependent SAP (sales profitability)

The value of coefficient summarizes the regression equation's aftereffects. So from coefficient table the variables which sig value is $(>0.05)$ point towards the rejection of that hypothesis and shows insignificant impact between independent variable which were CLM, ReiLEV, IR, RDGP and dependent variable INP, whereasGWP, MGE and SIZ shows significant impact on INP. The section B values examine the degree to which independent variable's estimation sum up to the dependent variable's estimation. Whereas "T value" which defines those variables that are independent contribute to the variable that was dependent INP (Investment Income).

The value of coefficient summarizes the regression equation's aftereffects. So from coefficient table the variables which sig value is $(>0.05)$ point towards the rejection of that hypothesis and shows insignificant impact between independent variable which were LEV, RGDP, CLM, Rei SIZE and dependent variable SAP, whereas GWP, MGE and IR shows significant impact on UWP.The section B values examine the degree to which independent variable's estimation sum up to the dependent variable's estimation. Whereas "T value" which defines those variables that are independent contribute to the variable that was dependent UWP (underwriting profit).

\subsection{Discussion}

Gross written premium (GWP) is found to be affecting the financial performance of the firms. As demonstrated by the outcomes of this research, the gross premium research does not impose a significant impact on the investment income, underwriting profit and sales profitability, yet, it has some impact on all these factors. All these factors can significantly lead to improvement in the financial performance of the firms. Yet, these factors are not influenced significantly by the gross written premium; however, the impact of this independent variable is positive. Salim (2018) examined the financial performance of the insurance companies in Bangladesh. The capital and asset should be maintained through reliable policies as they are the important drivers of profitability. In addition to this, researchers also revealed the impact of other aspects such as underwriting effects can affect the financial performance and can be used as an indicator of financial performance of the firms.

Claim (CLM) is also found to be associated with the financial performance of the firms. The losses on part of underwriting shows that it is due to high claim payments, high management expenses and overtrading. The 
results have also indicated that Claim, reinsurance leverage, interest rate and RDGP can affect investment income, yet the impact is not significant. Hsu-Hua et al. (2012) also conducted the study in similar context; however, the outcomes of this study were different from the present research. The researchers directed the investigation of reinsurance of property obligation of Taiwan and further also consider the impact of the firm size, Leverage, UR chance, Line of Business, Growth premium. The outcomes of this study revealed that ROA, ROI, liquidity proportion have a positive huge relationship and reinsurance, firm size, and money related influences, liquidity and degree of profitability emphatically and essentially and thus affecting financial performance of firms.

Management expenditure (MGE) and interest rate (IR) have significant impact on underwriting profit (UWP), yet the impact on the other financial aspect was not found to be significant. Agapova and McNulty (2016) demonstrated that interest rate and management expenditure can affect the financial performance of the firms. They evaluated the performance of insurance companies in terms of their financial standings in regards with the perception through regulators, managers, potential investors, owners and depositors. These factors can affect the performance of the firms by affecting different determinants of financial performance. The outcomes of this research also justified the outcomes of present research.

The size of firm affects the performance of the firms negatively. Further Size of the organization has the negative and significant impact on Investment income. Chen (2014) also demonstrated the similar effects that firm size has a significant impact on the performance of firms and this factor has significant negative effect. Anila (2015) has discussed the importance of investment Insurance in the development of the country's economy. The research performed a financial analysis through implementing financial ration of Insurance sector, with the focus on investment Insurance in Pakistan. Findings of the research indicated that the profitability of the Insurance lowered because of the great economic recession, however, the performance was found to be adequate. Thus, the outcomes of this study justified the present outcomes. Dr. Amal (2012) consider the determinant of execution of money related exercises of Jordanian Insurance industry. The outcome presented that Leverage, proportion of liquidity, Size of guarantors, the ability of the executives list positively affects the execution of budgetary exercises and thus ca affect the financial performance of firms. The outcomes also revealed that real gross domestic product (RGDP) have insignificant impact on underwriting profit (UWP) in insurance industry of Pakistan. Abdel (2014) analyzed the financial performance of Insurance companies in Pakistan and revealed that GDP can affect the financial performance of the insurance companies.

\section{Conclusion and Recommendations 6.1 Conclusion}

The study at hand was conducted on insurance sector of Pakistan and delved into gauging the financial performance of this sector. The financial performance of any sector needs to be evaluated in certain intervals in order to measure its growth and gather maximum benefits out of it. Financial Performance is important to measure as it has the tendency to play a crucial role in starting or putting into practice the technological innovations and organizational changes by making use of incentives for enhancing the performance and measurements to evaluate progress toward success. In the current study the financial performance of insurance sector of Pakistan was analyzed in depth by using the determinants of its profitability. The financial performance of insurance sector was measured on the basis of three dependent variables: investment income, underwriting profit and overall SAP. Using these three variables insurer can capture the key operations of Insurancesector. The underwriting profit and investment income can be summed up to gather the overall profitability of insurance companies. This is only possible when the underwriting profit and investment income work hand in hand by complementing each other's value.

The findings of the study show that Gross written profit, Management expenditure (MGE) and interest rate (IR) have significant impact on underwriting profit (UWP). Whereas, Claim, reinsurance, leverage (LEV), Size (SIZ) and real gross domestic product (RGDP) have insignificant impact on underwriting profit (UWP) in insurance industry of Pakistan. The losses on part of underwriting shows that it is due to high claim payments, high management expenses and overtrading. Furthermore, the study showed that Claim, reinsuranceleverage, interest rate and RDGP have insignificant relationship impact on investment income, whereas the Gross written profitmanagement expenditure and size shows positive and significant impact on (INP) investment income. Lastly, sales on profitability (SAP) impact was analyzed and found that MGE, IR CLM, Reiand SIZ have insignificant relationship on SAP, whereasGross written profit, LEV and RDGP have significant impact on SAP. The gross written premium overall has showed positive significant impact showing the significance of the core variable which is Gross written profitGWP. As in Pakistan the pattern of investing is becoming faster because of political strength is superior to in this decade and industry of insurance organizations are frequently put some part of GWP in activities of investment to create more benefit. As in Ghana Joseph et al, (2014) likewise found a similar outcome and have a positive huge effect on each of the three given measures which wereSales Profitability (SAP), Investment Income (INP), and Underwriting profit (UWP). Further research included that 
the expansion in Gross written profit GWP enhances the benefit of the center tasks of insurer and their general productivity. Kozak (2012) additionally uncovered a similar outcome.

In last, after considering the effect of endogenous variables the finding reveals that the GWP has a positive relationship with all three measure of profitability. However, in insurance GWP has considered as a core part of an industry and all the prediction and projections are based on it. GWP relationship with investment means in Pakistan companies invests proportionately as per growth or decline of GWP. It is also observed that the sales profit and underwriting profit is totally based on GWP. Further Size of the company has the negative significant impact on Sales and Investment profit.

Finally, subsequent to considering the impact of endogenous factors the finding uncovers that the GWP has a positive association with each of the three profitability proportion. Be that as it may, in insurance GWP has considered as a center piece of an industry and all the forecast and projections depend on it. GWP association with venture implies in Pakistan organizations contributes proportionately according to development or decrease of GWP. It is additionally seen that the SAP which was sales profit and UWP under writing profit is completely founded on GWP.

\subsection{Recommendations}

The country's performance on macro-economic factors with structural changes in insurance sector would definitely shows tangible improvements while improving financial strength of insurance industry as well. The usage and diversification of advanced insurance services have very constructive implications for insurance sector's profitability. The increase in profitability by declining the interest expense of the insurance sector also plays a significant role. With huge increase in profitability associated to these services, the risk exposure in shape of emerging liquidity constraints and rising maturity also poses a threat. That risk can be overcome by increased capital requirements by somewhat, the insurance company need to think on innovative ideas to mobilize its long term deposit in fruitful investments and further breakthrough in liability products.

In the recent times, Pakistan insurance industry has been subjected to improvements in size and structure through running reform processes and strong macroeconomic fundamentals. Pakistan insurance industry has witnessed a swift yet major shift of aggregated assets from public to private sector. This resulted in decreased asset concentration in this sector. Privatization is the main reason for these massive improvements and has impacted the performance of insurance company system in the long run. Despite the privatization of insurance company, intermediation spread has not reduced. Implying asset concentration has also found to be an important determinant of the intermediation spread. It further implies that improvement in asset concentration would improve efficiency of insurance sector significantly.

The results of this study are focused on the entire insurance industry as a whole. These results can be beneficial for the insurer and can serve as a guideline to the managers to utilize the resources and assets in the most optimum manner. For reliable and the authenticity of the result, it is recommended that researchers can expand the information collection or compare Pakistani industry to other countries with different nations to comprehend the better connection between variables both internal and external. Further, it is imperative to discover endogenous and exogenous factor which may, straightforwardly and in some way, effecting model. Furthermore, the researcher can likewise lead essential research including distinction conduct factors which may influence the insurer benefit.

\section{References}

Abdel k., (2014). Determinants of performance of insurance companies in Tunisia: the case of life insurance, International Journal of Innovation and Applied Studies, 6 (1), 90-96.

Agapova, A., \& McNulty, J. E. (2016). Interest rate spreads and Insurance system efficiency: General considerations with an application to the transition economies of Central and Eastern Europe. International Review of Financial Analysis, 47, 154-165. https://doi.org/10.1016/ j.irfa.2016.07.004

Ahmed, N., Ahmed, Z. \&Usman, A. (2015), Determinants of performance: a case of life insurance sector of Pakistan, International Research Journal of Finance and Economics, 61, 123-128.

Andrieş, A. M., \&Căpraru, B. (2014). Convergence of insurance company efficiency in emerging markets: The experienceof Central and Eastern Europeancountries. Emerging Markets Financeand Trade, vol. 50(4), pp. 9-30

Anila (2017), determinants of financial performance of the insurance companies: a case of Albania, International Journal of Economics, Commerce, and Management, 3(4),

Bosse, D. A., \& Phillips, R. A. (2016). Agency theory and bounded self-interest. Academy of Management Review, 41(2), 276-297.

Brusov, P., Filatova, T., Orekhova, N., \& Eskindarov, M. (2018). New Mechanism of Formation of the Company's Optimal Capital Structure, Different from Suggested by Trade-Off Theory. In Modern Corporate Finance, Investments, Taxation and Ratings (pp. 99-117). Springer, Cham. 
Căpraru, B., \&Ihnatov, I. (2014). Insurances’ profitabilityin selectedCentral andEastern European countries. Procedia Economics and Finance, 16, 587-591. https://doi.org/10.1016/S2212-5671(14)00844-2

Charumathi B.,(2012), On the Determinants of Profitability of Indian Life Insurers - An Empirical Study, Proceedings of the World Congress on Engineering,.

Chen (2014), The effects of firm-specific factors and macroeconomics on profitability of property-liability insurance industry in Taiwan, Asian Economic and Financial Review, 4(5), 681-691

Emine (2016), Financial Performance Assessment of Non-Life Insurance Companies traded in Borsa Istanbul via Grey Relational Analysis, International Journal of Economics and Finance, 8 (4)

Ferretti, V. (2016). From stakeholders analysis to cognitive mapping and Multi-Attribute Value Theory: An integrated approach for policy support. European Journal of Operational Research, 253(2), 524-541.

Georgievski, B., Antoun, R., \& Coskun, A. (2018) Determinants of financial performance of

Habib, A. (2015) A Comparison of Financial Performance of insurance Industry in Pakistan, Journal of Poverty, Investment and Development, Vol.13, pp.1-11

Habib, A., 2015. A comparison of Financial Performance of Insurance Industry in Pakistan. Journal of Poverty, Investment and Development, 13, pp.1-10.

Hamilton B.H, Nickerson J.A. (2003), Correcting for endogeneity in strategic management research. Strategic Organization 1 (1), $51-78$

Hsu-Hua, L. (2012), an Analysis of Reinsurance and Firm Performance: Evidence from the Taiwan PropertyLiability Insurance Industry, the Geneva Papers, 37, (467-484) \& the International Association for the Study of Insurance Economics 1018-5895/12.

Insurance companies in Central and Eastern Europe, Business and economic horizon, Vol 14, Issue 3, pp. 513529

John G.G., Samuel G.G, \& Richard K. A.,(2013), Degree of Financial and Operating Leverage and Profitability of Insurance Firms in Ghana, International Business and Management, 7(2), 57-65.

Juliana, A. (2012), Determinants of Family Takaful (Islamic Life Insurance) Demand: A Conceptual Framework for a Malaysian Study, International Journal of Business and Management, 7(6). Kozak, S. (2011), Determinants of profitability of non-life insurance companies in Poland during integration with the European financial system, Electronic Journal of Polish Agricultural Universities, 14(1).

Naseem, I., Saleem, A., Shah, Q. and Shah, A.A., 2012. The profitability of insurance sector in Pakistan: An empirical analysis from 2006-2010.

Salim, R. (2018), financial performance of commercial Insurances in the post-reform era: Further evidence from Bangladesh, data retrieved from https://www.researchgate.net/publication/322243885_Financial_performance_of_commercial_Insurances_i $\mathrm{n}$ the post-reform_era_Further_evidence_from_Bangladesh

Tahir, M., Shah, Q.A., Khan, M.M. and Afridi, M.A.A., 2018. Intellectual Capital and Financial Performance of insurance companies in Pakistan. Dialogue (Pakistan), 13(1). 